\title{
KEJADIAN SEKSIO CAESAREA PADA PASIEN RAWAT INAP RSUD DR. SOEKARDJO.
}

\author{
Gustiani Nur Ruchmayanti ${ }^{1}$, Sofia Februanti ${ }^{2}$, Tetet Kartilah ${ }^{3}$ \\ ${ }^{1}$ Alumni Prodi KeperawatanTasikmalaya, ${ }^{2,3}$ Dosen Prodi KeperawatanTasikmalaya \\ Email: sofiafebruanti@gmail.com
}

\begin{abstract}
Abstrak
Tujuan penelitian ini adalah untuk mengetahui gambaran kejadian seksio caesarea (SC). Metode yang digunakan dalam penelitian ini adalah deskriptif. Sample dalam penelitian ini berjumlah 50 pasien, dengan teknik pengambilan sampel menggunakan accidental sampling. Hasil penelitian menunjukkan bahwa karakteristik pasien berdasarkan jenis SC pada pasien rawat inap di Ruang 1 RSUD dr. Soekardjo di dapatkan data presentase tertinggi adalah Jenis SC Elektif yaitu sebanyak 34 orang $(68,0 \%)$, umur $20-35$ tahun yaitu sebanyak 38 orang atau $(76,0 \%)$, Menengah kebawah yaitu sebanyak 29 orang $(58,0 \%)$, tidak bekerja yaitu sebanyak 33 orang $(66,0 \%)$, Multipara yaitu sebanyak 32 orang $(64,0 \%)$, tinggi badan lebih dari $145 \mathrm{~cm}$ yaitu sebanyak 38 orang $(76,0 \%)$,dan penyebab SC dengan Riwayat SC, KPD dan faktor bayi masing-masing sebanyak 9 orang $(18,0 \%)$. RSUD dr. Soekardjo hendaknya melakukan upaya preventif dengan memberikan pelayanan antenatal care sehingga indikasi penyulit kehamilan dapat dikendalikan secara dini, dan meningkatkan dalam pelayanan perawatan pada pre-operasi, intra-operasi dan post-operasi terkait dengan pencegahan infeksi dan komplikasi, serta memberikan edukasi berupa perawatan luka dan perencanaan kehamilan serta persalinan selanjutnya.
\end{abstract}

Kata Kunci: jenis, penyebab, Seksio Caesarea.

\begin{abstract}
The purpose of this study was to describe the events section to caesarea. The method used in this research is descriptive. Sample in this study was 50 patients, with a sampling technique used accidental sampling. The results showed that the characteristics of the patient based on the type SC on inpatients in Room 1 at RSUD dr. Soekardjo in getting the highest percentage of data is the type SC elective that as many as 34 people (68.0\%), aged 20-35 years, or as many as 38 people (76.0\%), Intermediate down as many as 29 people (58.0\%), does not work as many as 33 people (66.0\%), Multipara as many as 32 people (64.0\%), height more than $145 \mathrm{~cm}$ as many as 38 people (76.0\%), and the cause SC with SC history, KPD and infant factors respectively of 9 (18.0\%). RSUD dr. Soekardjo should perform preventive efforts by providing services antenatal care so that indications of pregnancy complications can be controlled at an early stage, and increase in care services in the pre-operative, intra-operative and post-operative associated with the prevention of infections and complications, as well as provide education in the form of wound care and planning pregnancy and subsequent birth.
\end{abstract}

Keywords: types, causes, seksio caesarea.

\section{PENDAHULUAN}

Setiap wanita menginginkan

persalinannya berjalan lancar dan dapat melahirkan bayi dengan sempurna. Ada dua cara persalinan yaitu persalinan lewat vagina yang lebih dikenal dengan persalinan alami dan persalinan caesar atau section caesarea. Persalinan section caesarea (SC) adalah sebuah tindakan operasi untuk mengeluarkan bayi dengan melalui insisi pada dinding perut

dan didnding rahim dengan syarat rahim dalam keadaan utuh serta berat janin diatas 500 gram (Wiknjosatro, 2007).

Angka kejadian SC di Indonesia mengalami peningkatan pada tahun 2000 jumlah ibu bersalin dengan SC $47,22 \%$, tahun 2001 sebesar 45, $19 \%$, tahun 2002 sebesar $47,13 \%$, tahun 2003 sebesar $46,87 \%$, tahun 2004 sebesar53,2\%, tahun 2005 sebesar 
$51,59 \%$, dan tahun 2006 sebesar $53,68 \%$ dan tahun 2007 belum terdapat data yang signifikan (Grace, 2007 dalam Sumelung dkk, 2014). Hasil Riset Kesehatan Dasar (Riskesdas) tahun 2013 menunjukkan bahwa kelahiran melalui SC sebesar 9,8 persen dengan proporsi jawa barat $7 \%$ dan merupakan provinsi ke 17 dalam proporsi kelahiran secara $S C$ dari 33 provinsi di Indonesia. Sedangkan data dari rekap medis RSUD dr. Soekardjo pada tahun 2015 didapatkan data sebanyak 3132 persalian dengan 606 kasus dilakukan tindakan SC.

Indikasi yang menyebabkan tingginya angka persalinan SC menurut Cunningham (2006); Mariroh (2013); dan Prawirohardjo (2007) adalah faktor ibu; pre-eklamsia dan eklamsi; distosia; riwayat SC; ketuban pecah dini; kelainan plasenta; cephalopelvic disproportion. Adapun dari faktor bayi adalah; pada kehamilan kembar; gawat janin; dan letak lintang. Faktor lainnya adalah faktor sosio-demografi yaitu; umur, pendidikan, pekerjaan, sosial dan ekonomi. Faktor mediko-obstetri; paritas, jarak persaliana dan riwayat obstetri jelek serta faktor gizi (Marisi, 2008 dalam Mursalim, 2012).

Berdasarkan studi pendahuluan yang dilakukan oleh peneliti diperoleh informasi bahwa angka persalinan SC pada tahun 2015 adalah 606 pasien SC dari 3132 pesalinan. Hasil wawancara dengan 6 orang pasien SC, didapatkan data 6 responden berusia antara 20-35 tahun, 4 responden merupakan kelahiran anak pertama (nuliprada) dengan penyebab 2 responden dengan bayi sungsang, 1 responden pre-eklampsi, dan 1 responden terjadi ketuban pecah dini. 2 responden lainnya merupakan kelahiran anak kedua (primipara) dengan penyebab riwayat SC sebelumnya. Berdasarkan fenomena tersebut, peneliti merasa tertarik untuk mengadakan penelitian tentang gambaran kejadian sectio caesarea pada pasien rawat inap di Ruang 1 di RSUD dr. Soekardjo.

\section{METODE PENELITIAN}

Desain penelitian yang digunakan adalah desain deskriptif. Populasi dalam penelitian ini adalah semua pasien yang di SC berjumlah
203 pada bulan September sampai Desember 2015 yang berada di Ruang 1 RSUD dr. Soekardjo Tasikmalaya. Teknik sampling yang digunakan accidental sampling, dengan jumlah responden yang diperlukan 50 orang responden. Kriteria inklusi adalah pasien yang sudah dilakukan tindakan SC; dan bersedia berpartisipasi dalam penelitian. Jenis instrumen penelitian adalah lembar observasi. Analisa data dengan menggunakan analisis univariate.

\section{HASIL PENELITIAN}

Tabel 1. Distribusi frekuensi Kejadian Seksio Caesarea Berdasarkan Jenis SC

\begin{tabular}{|c|c|c|}
\hline KATEGORI & FREKUENSI & $\%$ \\
\hline \multicolumn{3}{|l|}{ Jenis SC: } \\
\hline SC Elektif & 34 & $68 \%$ \\
\hline SC Emergency & 16 & $32 \%$ \\
\hline \multicolumn{3}{|l|}{ Umur: } \\
\hline$<20$ tahun & 5 & $10 \%$ \\
\hline 20-35 tahun & 38 & $76 \%$ \\
\hline$>35$ tahun & 7 & $14 \%$ \\
\hline \multicolumn{3}{|l|}{ Pendidikan Terakhir: } \\
\hline$\leq \mathrm{SMP}$ & 29 & $58 \%$ \\
\hline$>$ SMP & 21 & $42 \%$ \\
\hline \multicolumn{3}{|l|}{ Pekerjaan } \\
\hline Bekerja & 17 & $34 \%$ \\
\hline Tidak Bekerja & 33 & $66 \%$ \\
\hline \multicolumn{3}{|l|}{ Paritas } \\
\hline Primipara & 18 & $36 \%$ \\
\hline Multipara & 32 & $64 \%$ \\
\hline \multicolumn{3}{|l|}{ Tinggi Badan } \\
\hline$\leq 145 \mathrm{~cm}$ & 12 & $24 \%$ \\
\hline$>145 \mathrm{~cm}$ & 38 & $76 \%$ \\
\hline \multicolumn{3}{|l|}{ Penyebab SC } \\
\hline \multicolumn{3}{|l|}{ Faktor ibu: } \\
\hline Pre Eklasmsia / & 8 & $16 \%$ \\
\hline Eklamsi & 4 & $8 \%$ \\
\hline Kelainan Placenta & 9 & $18 \%$ \\
\hline Riwayat SC & 3 & $6 \%$ \\
\hline Kelainan Kontraksi & 9 & $18 \%$ \\
\hline KPD & 1 & $2 \%$ \\
\hline CPD & 7 & $14 \%$ \\
\hline \multicolumn{3}{|l|}{ Penyakit Lain } \\
\hline Faktor Bayi & 4 & $8 \%$ \\
\hline Bayi terlalu besar & 0 & $0 \%$ \\
\hline Bayi kembar & 0 & $0 \%$ \\
\hline $\begin{array}{l}\text { Gawat janin } \\
\text { Kelainan letak janin }\end{array}$ & 5 & $10 \%$ \\
\hline
\end{tabular}

Berdasarkan tabel 1. angka kejadian SC berdasarkan jenis SC pada pasien rawat inap di Ruang 1 RSU dr. Soekardjo sebagian besar melakukan SC elektif yaitu sebanyak 34 orang $(68,0 \%)$, sebanyak 38 orang atau $(76,0 \%)$ berumur dari $20-35$ tahun yang 
melakukan SC, sebagian besar berpendidikan terakhir S SMP yaitu sebanyak 29 orang $(58,0 \%)$, sebagian besar merupakan ibu yang tidak bekerja yaitu sebanyak 33 orang $(66,0 \%)$, sebagian besar merupakan paritas Multipara yaitu sebanyak 32 orang $(64,0 \%)$, sebagian besar memiliki tinggi badan $>145$ $\mathrm{cm}$ yaitu sebanyak 38 orang $(76,0 \%)$. Angka kejadian SC berdasarkan penyebab dilakukan SC paling sering pada pasien rawat inap di Ruang 1 RSU dr. Soekardjo adalah responden dengan KPD dan riwayat SC sebanyak 9 orang $(18,0 \%)$, faktor bayi sebanyak 9 orang $(18,0 \%)$ dengan Kelainan posisi bayi sebanyak 5 orang $(10,0 \%)$ dan kelainan letak janin 4 orang $(8,0 \%)$.

\section{PEMBAHASAN}

Penelitian Andayasari, dkk (2014) terhadap ibu yang melakukan tindakan SC dengan hasil yang dilakukan pada kelompok umur 21-35 tahun dengan persalinan sesarea persalinan sesarea elektif $77 \%$. SC terencana (elektif) yaitu tindakan operasi bedah yang direncanakan lebih dahulu. Kondisi ini dilakukan apabila dokter menemukan ada masalah kesehatan pada ibu atau ibu menderita suatu penyakit, sehingga tidak memungkinkan untuk melahirkan secara normal, misalnya ibu menderita diabetes, HIV/AIDS, ataupun penyakit jantung, janin dengan presentasi bokong, kehamilan kembar, janin dengan oligohidramnion (cairan ketuban sedikit) atau janin dengan gangguan perkembangan (Oxorn and Forte, 2010).

Banyaknya ibu yang dilakukan SC elektif, dikarenakan riwayat SC sebelumnya, ibu dengan penyakit penyerta seperti asma, jantung dan diabetes. Kelainan letak bayi seperti presentasi bokong, kelainan placenta atau placenta previa, CPD, kelainan kontraksi, dan bayi terlalu besar. Sehingga ibu direncanakan sebelumnya melakukan tindakan operasi SC untuk menyelamatkan keadaan ibu dan bayi. Serta meningkatnya pengetahuan ibu tentang perencanaan persalinan yang sesuai dengan kebutuhan.

Hasil penelitian yang dilakukan Siregar, dkk (2012) menunjukkan bahwa proporsi ibu bersalin dengan SC berdasarkan umur terbesar adalah pada kelompok 20-35 tahun sebanyak 68 orang $(78,20 \%)$ dan terkecil adalah kelompok umur $<20$ tahun dan $>35$ tahun sebanyak 19 orang $(21,80 \%)$. Lebih lanjut penelitian yang dilakukan Sinaga (2009) di RSUD Sindikalang Medan, menyatakan bahwa distribusi proporsi umur terbesar pada tindakan SC menurut umur adalah pada kelompok umur 20-35 tahun 78,7\%, dan yang terendah adalah umur $<20$ tahun dan $>35$ tahun $21,3 \%$

Secara umum, berdasarkan hasil penelitian, didapatkan kelompok umur yang paling banyak menjalani persalinan secara SC maupun pervaginam yakni pada umur 2035 tahun. Usia di bawah 20 tahun merupakan usia dengan risiko tinggi untuk kehamilan dan persalinan karena usia ini masih merupakan masa pertumbuhan seorang ibu, sedangkan usia di atas 35 tahun juga digolongkan ke dalam kehamilan risiko tinggi karena pada usia ini terjadi penurunan fisik dan biologis ibu (Cunningham, 2007).

Kelompok umur 20-35 tahun merupakan usia yang aman untuk menjalani persalinan, juga terdapat faktor-faktor predisposisi yang menyebabkan seorang Ibu menjalani SC, baik yang berkaitan erat dengan reproduksi seperti paritas, komplikasi 3P (Power, Passanger, Passage) ataupun kurangnya pemanfaatan ANC, serta kurangnya asupan gizi saat masa kehamilan, dan angka kejadian SC yang tidak dikendalikan di usia produktif ibu.

Hasil penelitian yang dilakukan oleh Kusumawati (2007) didapatkan bahwa ibu yang melakukan SC berdasarkan tingkat pendidikan responden pada kelompok sebagian besar kasus adalah tamat SLTP/SMP sebanyak $46,6 \%$ dan untuk responden yang berpendididkan SLTA/SMA sebnyak $38,8 \%$. Hasil berbeda yang dilakukan Siregar, dkk (2012) di RSUD dr. Pringadi Medan, Berdasarkan tingkat pendidikan terbesar adalah Tamat SLTA/sederajat yaitu sebanyak 73 orang $(83,91 \%)$ dan terkecil adalah tidak tamat SD/tamat SD/sederajat sebanyak 3 orang $(3,45 \%)$, dimana responden yang memiliki pendidikan lebih tinggi banyak melakukan SC. 
Pendidikan adalah sesuatu yang dapat membawa seseorang untuk memiliki ataupun meraih wawasan dan pengetahuan seluasluasnya. Semakin tinggi pendidikan seseorang maka semakin mudah baginya untuk mengerti dan memahami tentang resiko-resiko yang akan di alami pada proses persalinan yang akandi hadapi. Orang-orang yang memiliki pendidikan yang lebih tinggi akan memiliki wawasan dan pengetahuan yang lebih luas jika dibandingkan dengan orang-orang yang memiliki pendidikan yang lebih rendah (Notoatmodjo, 2003).

Hubungan pendidikan dengan tindakan SC menunjukan semakin tinggi pendidikan seseorang maka akan semakin cepat memahami tentang resiko persalinan yang akan di hadapi. Semakin tinggi pendidikan seseorang maka semakin mudah baginya untuk mengerti dan memahami tentang resiko-resiko yang akan di alami pada proses persalinan yang akan dihadapi, dapat membuat keputusan persalian operatif atau tidak. Selain itu faktor budaya dan pengaruh lingkungan pasien. Persalinan secara SC dapat memberikan keuntungan berupa mengurangi angka kesakitan pada ibu dan mengurangi resiko pada bayi dan sekaligus resiko untuk terjadinya pendarahan, parut dalam rahim, dan cidera pada organ lain bagi ibu sebagai pasien, untuk membuat keputusan dilakukan SC atau tidak seseorang perlu pengetahuan yang cukup tentang tujuan, keuntungan dan kerugian baik bagi bayi, ibu dan keluarga.

Sejalan dengan hasil penelitian yang dilakukan Siregar, dkk (2012) di RSUD dr. Pringadi Medan, berdasarkan pekerjaan terbesar adalah ibu rumah tangga sebanyak 66 orang $(75,86 \%)$ dan terkecil adalah pegawai swasta/wiraswasta sebanyak 7 orang $(8,05 \%)$. Hasil berbeda dari penelitian Sinaga (2009), berdasarkan proporsi pekerjaan ibu yang terbesar dalam tindakan SC yang dilakukan adalah petani $50,8 \%$, kemudian Ibu Rumah Tangga 26,3\%, pegawai swasta/wiraswasta $12,4 \%$, dan yang terendah adalah pegawai negeri sipil $10,5 \%$.

Derajat sosial ekonomi masyarakat akan menunjukkan tingkat kesejahteraan dan kesempatannya dalam menggunakan dan menerima pelayanan kesehatan. Jenis pekerjaan ibu maupun suaminya akan mencerminkan keadaan sosial ekonomi keluarga (Wirakusumah, 1994 dalam Mursalim 2012).

Pekerjaan menunjukkan tingkat kesejahteraan dan kesempatannya dalam menggunakan dan menerima pelayanan kesehatan. Beberapa alasan yang mendasari kecenderungan melahirkan dengan SC semakin meningkat pada para ibu yang bekerja, karena mereka sangat terikat dengan waktu dan sudah memiliki jadwal tertentu seperti kapan harus bekerja kembali (Role, 2005 dalam Annisa 2011). Dengan dilakukan SC ibu bekerja dapat menggatur jadwal kelahiran yang dapat disesuaikan dengan pekerjaan (Pillitteri, 2002 dalam Annisa 2011) tetapi dalam hasil penelitian banyak dilakukan pada ibu yang tidak bekerja.

Pekerjaan berkaitan erat dengan pendidikan dan pengetahuan responden. Ibu yang bekerja biasanya memiliki pendidikan yang lebih tinggi serta pengetahuan yang baik dari pada ibu yang tidak bekerja, karena ibu yang bekerja terpapar informasi dari rekanrekan pekerjanya, kemungkinan informasi kesehatan yang didapat lebih baik dari pada ibu yang tidak bekerja. Selain itu penggunaan asuransi kesehatan seperti BPJS, yang menjamin semua lapisan masyarakat berkesempatan sama untuk mengaskses pelayanan kesehatan yang lebih baik termasuk bagi ibu yang tidak bekerja, memiliki kesempatan untuk mendapatkan pelayanan yang terjangkau sesuai kebutuhan masingmasing termasuk pelayanan kooperatif yang berbiaya mahal.

Sejalan dengan penelitian Sari (2010) di RSUD dr. soedarso Pontianak dapat dilihat bahwa persalianan SC berdasarkan paritas yaitu Primipara sebanyak 147 responden dan Multipara sebanyak 157 responden. Berbeda dengan penelitian Sinaga (2007) persalinan seksio sesarea terbanyak dilakukan oleh ibu primipara $(42 \%)$, diikuti oleh ibu multipara (36\%), nulipara (19\%), grandemultipara (3\%).

Paritas adalah jumlah persalinan yang pernah dialami oleh ibu sebelum kehamilan 
atau persalinan saat ini. Semakin sering ibu mengalami kehamilan maka akan menimbulkan jaringan fibrotik pada vilichorialis plasenta dan berisiko mengalami hambatan dalam pertumbuhan dan perkembangan janin (Rahman, 2008 dalam Ekayani 2014). Menurut Prawirohardjo, (2007) paritas dapat dibedakan menjadi primipara, multipara dan grandemultipara. Hal ini memperlihatkan bahwa terjadi kecenderungan anak pertama yang dilahirkan secara SC.

Tinggi badan pendek $(<145 \mathrm{~cm})$ merupakan faktor risiko untuk seksio sesarea darurat dan juga tindakan pervaginam. Hasil penelitian sejalan dengan penelitian Mulyawati (2011) Sebagian besar responden mempunyai tinggi badan $\geq 145 \mathrm{~cm}$ yaitu dengan jumlah 58 responden $(96,7 \%)$ dan responden dengan tinggi badan $\leq 145 \mathrm{~cm}$ dengan jumlah 2 responden (3,3\%).

Tinggi badan merupakan faktor biologis namun dapat menunjukan pola status gizi seorang ibu. Karena tinggi badan pendek menunjukan pertumbuhan badan yang kurang optimal sehingga akan berpengaruh pada bentuk atau postur tubuh. Tinggi badan yang pendek biasanya mempunyai bentuk panggul yang sempit, tidak proposional jalan lahir kepala (Gifford, 2000 dalam kusumawati 2006)

Tinggi badan berkaitan erat dengan status gizi seseorang. Secara umum kekurangan gizi, akan berpengaruh terhadap kekuatan, daya tahan dan respon imun yang berpengaruh pada kehamilan ibu. Hal ini sejalan dengan pendapat Supariasa (2002) yang menyatakan bahwa upaya untuk menjaga, melindungi dan meningkatkan kesehatan dengan asupan gizi yang memenuhi akan sangat bermakna agar dapat mempertahankankesehatan. Tetapi dalam penelitian yang dilakukan $>145$ lebih banyak ada beberapa faktor yang mempengaruhinya yaitu gaya hidup seorang ibu, dengan asumsi bahwa dengan melakukan SC dapat mengurangi kesakitan pada ibu dan bayi tetapi tidak mengetahui bahaya yang akan ditimbulkan dari operasi SC tersebut, sehingga kurang terpaparnya informasi mengenai kesehatan tentang kehamilan,
Riwayat Kunjungan ANC yang jarang dan asupan gizi saat hamil yang kurang.

Banyaknnya ibu yang mengalami operasi bedah SC karena ibu memiliki riwayat SC sebelumnya, serta bayi yang terlalu besar dan kelainan letak janin yang menyebabkan terjadinya operasi SC. Ketuban pecah dini (KPD) mempunyai kontribusi yang besar pada kematian perinatal pada bayi (Nugroho, 2013), sehingga KPD juga mempengaruhi terhadap peningkan terjadinya tindakan pembedahan SC. Meningkatnya kesadaran ibu tetang tujuan untuk mengurangi kesakitandan faktor-faktor yang mendorong terjadinya resiko tinggi pada bayi.

\section{KESIMPULAN}

Jenis SC pada pasien rawat inap di Ruang 1 RSU dr. Soekardjo di dapatkan data presentase tertinggi adalah ibu dengan Jenis SC Elektif yaitu sebanyak 34 orang $(68,0 \%)$, dengan umur 20-35 ahun yaitu sebanyak 38 orang atau $(76,0 \%)$, ibu pendidikan terakhir $\leq$ SMP yaitu sebanyak 29 orang $(58,0 \%)$, ibu dengan tidak bekerja yaitu sebanyak 33 orang $(66,0 \%)$, ibu dengan paritas Multipara yaitu sebanyak 32 orang $(64,0 \%)$, dan ibu dengan tinggi badan $>145 \mathrm{~cm}$ yaitu sebanyak 38 orang $(76,0 \%)$, penyebab SC adalah ibu dengan Riwayat SC, KPD dan faktor bayi yaitu masing-masing sebanyak 9 orang $(18,0 \%)$.

\section{SARAN}

Hasil penelitian ini diharapkan pihak Rumah sakit dan tenaga kesehatan lebih meningkatkan dalam pemberian pelayanan kesehatan yang diberikan kepada masyarakat. Sehingga menurunkan angka kejadian SC dan pengendalian dampak terjadinya SC. Serta Rumah sakit juga berperan dalam upaya preventif bagi ibu dengan memberikan pelayanan Antenatal Care sehingga indikasi penyulit kehamilan dapat dikendalikan secara dini seperti faktor bayi yaitu bayi sungsang ataupun bayi terlalu besar, serta perlu meningkatkan dalam pelayanan perawatan pada pre-operasi, intraoperasi dan post-operasi terkait dengan pencegahan infeksi dan komplikasi, serta 
memberikan edukasi berupa perawatan luka dan perencanaan kehamilan serta persalinan selanjutnya.

\section{REFERENSI}

Afriani, A., (2013). Kasus Persalinan Dengan Bekas Seksio Sesarea Menurut Keadaan Waktu Masuk di Bagian Obstetri dan Ginekologi RSUP Dr. M. Djamil Padang. Di unduh tanggal 04 maret 2016 http://jurnal.fk.unand.ac.id.

Andayasari, dkk., (2014). Proporsi Seksio Sesarea dan Faktor yang Berhubungan dengan Seksio Sesarea di Jakarta. Di unduh tanggal 12 juni 2016 http://ejournal.litbang.depkes.go.id

Andriani, D., (2012). Faktor-Faktor Faktor Yang Mempengaruhi Tindakan Seksio Sesarea Di Rumah Sakit Umum Daerah Dompu. Tahun 2010 di unduh 04 maret2016 http://lib.ui.ac.id.

Annisa, S., (2011). Faktor-Faktor Risiko Persalinan Seksio Sesarea Di Rsud Dr. Adjidarmo Lebak Pada Bulan OktoberDesember 2010. Di unduh tanggal 01 maret 2016 perpus.fkik.uinjkt.ac.id.

Arikunto, S., (2013). Prosedur Penelitian Suatu Pendekatan Praktek. Jakarta: Rineka Cipta

Cunningham, (2009). Ostetri Williams. Jakarta: EGC

Ekayani, N., (2014). Faktor Sosio demografi, Medis Maternal, Status Gizi Dan Pemeriksaan Antenatal Yang Rendah Meningkatkan Risiko Kejadian Berat Badan Lahir Rendah Di Kota Mataram Propinsi Nusa Tenggara Barat. Diunduh tanggal $03 \quad$ maret 2016 Ipsdimataram.com

Hartatik, S., (2014). Profil Umur Dan Pekerjaan Ibu Bersalin Sectio Caesarea Yang Mempunyai Riwayat Sectio Caesare. Diunduh tanggal 05 maret 2016 http://jurnalgriyahusada.com

Hidayat dan Sujiyanti, (2010). Asuhan Kebidanan persalinan. Yogyakarta: Nuha Medika

Hidayat, A., (2007). Riset Keperawatan Dan Tekik Penulisan IImiah. Jakarta: Salemba Medika
Isti, dkk., (2011). Faktor Tindakan Persalinan Operasi Sectio Caesarea. Diunduh tanggal 24 februari 2016 http://journal.unnes.ac.id.

Kusumawati, Y., (2006). Faktor-faktor yang memepengaruhi terhadap persalianan dengan tindakan. Di unduh tanggal 01 Maret 2016. https://core.ac.uk.

Lenovo, K., (2009). Ostetri Williams. Jakarta: EGC

Manuaba, I., (2010). IImu Kebidanan, Penyakit Kandungan Dan KB. Jakarta: EGC

Masriroh, (2013). Keperawatan Obstetri Dan Ginekologi. Yogyakarta: Imperium

Mulyawati, dkk., (2011). Faktor Tindakan Persalinan Operasi Sectio Caesarea. Di unduh tanggal 12 Juni 2016 http://journal.unnes.ac.id.

Mursalim, K., (2012). Faktor Determinan Pemilihan Jenis Persalinan dan Dampaknya Terhadap Pemberian ASI. Diunduh $01 \quad$ maret 2016 repositoy,unhas.ac.id

Notoatmodjo, S., (2007). Pendidikan dan Perilaku Kesehatan. Jakarta: Rineka Cipta (2010). Metodologi penelitian kesehatan. Edisi Revisi. Jakarta: Rineka Cipta

Nugroho, (2013). Buku Ajar Obsterteri. Yoygakarta: Nuha Medika

Nursalam.(2008). Konsep dan Penerapan Metodologi Penelitian IImuKeperawatan : Pedoman Skripsi, Tesis, dan Instrumen. Edisi 2. Jakarta :Salemba Medika , (2013). Metodologi Penelitian IImu Keperawatan Pendekatan Praktis. Jakarta : Salemba Medika.

Oxorn dan Forte, (2010). Ilmu Kebidanan Patologi Dan Fisiologi Persalinan. Yogyakarta: Yayasan Essentia Medika.

Prawirohardjo, S. (2006). IImu bedah kebidanan. Jakarta: bina pustaka (2007). IImu bedah kebidanan. Jakarta: bina pustaka

Riset Kesehatan Dasar, (2013). Pelayanan Kesehatan Masa Kehamilan, Persalinan, Dan Nifas. Di unduh tanggal 14 maret 2016 http://www.depkes.go.id. 
Rekap Medis RSU Dr. Soekardjo, (2014). Data persalinan seksio caesaea di ruang 1 RSUD dr. Soekardjo Tasikmalaya.

Sinaga, E.M., (2007). Karakteristik ibu yang mengalami persalinan dengan seksio sesarea yang dirawat inap di Rumah Sakit Umum Daerah Sidikalang. Di unduh tanggal 12 juni 2016 http://repository.usu.ac.id.

Sandi, (2011). Gambaran kasus seksio sesarea berdasarkan status rujukan di RSU Dokter Soedarso Pontianak Periode 1 Januari - 31 Desember 2011. Tanggal 04 Maret 2016 http://jurnal.untan.ac.id.

Sari, N., (2007). Gambaran Kasus Persalinan Seksio Sesarea Di RsudDr.Soedarso Pontianak. Di unduh tanggal 12 Juni $2016 \mathrm{http}: / /$ download.portalgaruda.org.

Setiadi, (2007). Konsep dan penulisan riset keperawatan. Yogyakarta: Graha IImu

Silalahi, U., (2010). Meode Penelitian Sosial. Bandung : Refika Aditama
Siregar, dkk. (2012).Karakteristik lbu Bersalin Dengan Sectio Caesarea Di RumahSakit Umum Daerah Dr. Pirngadi Medan Tahun 2011-2012. Di unduh tanggal12 Juni 2016 http://202.0.107.5.

Sumelung, dkk, (2014). Faktor-faktor yang berperan meningkatnya angka kejadian sectio caesarea di Rumah Sakit Umum Daerah Liun Kendage Tahunan. Di unduh pada tanggal 24 februari 2016 http://jurnal.untan.ac.id.

Sukarni dan Wahyu, (2013). Buku Ajar Keperawatan Maternitas. Yogyakarta: Nuha Medika

Supariasa, (2002). Penilaian Status Gizi. Jakarta: EGC

Varney, H., (2008). Buku Ajar Asuhan Kebidanan. Jakarta:EGC

Winknjosastro, dkk. (2007). IImu Bedah Kebidanan. Jakarta: Yayasan bina pustaka sarwono prawirohardjo. 